\title{
Organic and Inorganic Sources of Fertilizers Affect the Yield Attributes, Yield of Bottle Gourd [Lagenaria siceraria (Mol.) Standl] and Modified Soil Physico-chemical Properties in Eastern Uttar Pradesh
}

\author{
Sanjay Kumar ${ }^{1}$, Satendra Kumar Singh ${ }^{2}$ and Surendra Prasad ${ }^{3 *}$ \\ ${ }^{1}$ Department of Agricultural Chemistry, ${ }^{2}$ Department of Horticulture, Baba Raghav Das Post \\ Graduate College, Deoria, Uttar Pradesh, India \\ ${ }^{3}$ Krishi Vigyan Kendra, Manjhi, Saran, Dr. Rajendra Prasad Central Agricultural University, \\ Pusa, Samastipur, Bihar, India \\ *Corresponding author
}

A B S T R A C T

\begin{tabular}{|c|}
\hline Keywords \\
\hline $\begin{array}{l}\text { Organic and } \\
\text { inorganic fertilizers, } \\
\text { Bottle gourd, yield, } \\
\text { Available nutrients }\end{array}$ \\
\hline Article Info \\
\hline $\begin{array}{l}\text { Accepted: } \\
20 \text { June } 2020 \\
\text { Available Online: } \\
10 \text { July } 2020\end{array}$ \\
\hline
\end{tabular}

A field experiment was established at Agricultural Research Farm of Baba Raghav Das Post Graduate College, Deoria (U.P.), to evaluate the influence of organic and inorganic fertilizers on performance of bottle gourd and plant available nutrients. The experiment comprised eleven treatments and three replications performed under Randomised Block Design during summer season (2017 \& 2018). Average of two years data revealed that application of organic and inorganic fertilizers $\left(T_{8}, T_{9}, T_{10}, T_{11} \& T_{3}\right)$ significantly improves the yield attributes (viz., vine length, number of primary branches per vine, maximum number of fruit per vine and days taken to appearance first female flower) as well as yield of bottle gourd in comparison with control. The yield of bottle gourd was also significantly improved by $97.7-111.0 \%$ in treatments $\mathrm{T}_{8}, \mathrm{~T}_{9}, \mathrm{~T}_{10}, \mathrm{~T}_{11} \& \mathrm{~T}_{3}$ over control due to combined application of organic and inorganic fertilizers as well as better yield attributes. Availability of plant nutrients i.e., available N, P, K \& S were also significantly improved in treatments (viz., $\mathrm{T}_{8}, \mathrm{~T}_{9}, \mathrm{~T}_{10}, \mathrm{~T}_{11}$ and $\mathrm{T}_{3}$ ) having combination of organic and inorganic fertilizers. In conclusion, the application of 10 tonnes vermicompost/ha $+25 \%$ RDF $\left(\mathrm{T}_{8}\right)$ and 7.5 tonnes of vermicompost/ha $+50 \%$ RDF $\left(\mathrm{T}_{9}\right)$ were performed better for yield attributes \& yield of bottle gourd, as well as availability of plant available soil nutrients in Eastern Uttar Pradesh.

\section{Introduction}

Bottle gourd is an important vegetable crop grown in India. The fruit of bottle gourd can be used as vegetable and making sweet (halwa, kheer, petha and barfi) and pickles. As a vegetable it is easily digestible, even by patients. A decoction made from the leaf is a very good medicine for curing jaundice (Thamburaj and Singh, 2008). The fruit has a cooling effect, it is a cardiatonic and diuretic. Nutritionally it contains medium quality of carbohydrates, vitamin and minerals. In India, it is commercially grown in the Indo-Gangatic belt of northern belt as summer and kharif crops. 
The integrated use of organics and inorganic fertilizers has received considerable attention in the recent past with a hope of meeting the farmer's economic need as well as maintaining favourable ecological conditions on a long-term basis. Soil organic matter greatly effectives the biology of the soil, hence, it given most of energy and body building constituents of the microorganism whose transformation of unavailable nutrient to available nutrient utilised by crops and produce higher yield as well as soil fertility also improved. Soil organic matter is a various type mixture of organic substances (Brady and Weil, 2002).

An organics has the potential to increase cation exchange capacity, water holding capacity and other soil properties of cultivated soil. It also contains higher quantities of plant nutrients and slow release store house of nutrient, especially nitrogen, phosphorus and sulphur. Soil organic matter have certain organic compounds found in have direct growth enhancing effect on plant growth. Therefore, the aim of the study was to evaluate the effect Organic and Inorganic sources of Fertilizers on yield attributes, yield and physic-chemical properties of soil under Bottle gourd.

\section{Materials and Methods}

The experiment was established at Agricultural Research Farm of Baba Raghav Das Post Graduate College, Deoria (U.P.), Affiliated to Deen Dayal Upadhyay Gorakhpur University, Gorakhpur (U.P.) during spring summer season of 2017 and 2018 to study the influence of organic and inorganic fertilizers on performance of bottle gourd variety 'Pusa Naveen' and plant available nutrients. The soil of the experimental site was sandy loam in texture with almost neutral $\mathrm{pH}$ (7.8), medium organic carbon $(3.6 \mathrm{~g} / \mathrm{kg})$, low available nitrogen \& phosphorus (203. $0 \& 16.30 \mathrm{~kg} / \mathrm{ha})$, and high available potassium $(180.0 \mathrm{Kg} / \mathrm{ha})$. The experiment was laid out in Randomized Block Design (RBD) with replicated thrice within block involved eleven treatments viz., $\mathrm{T}_{1}$ control, $\mathrm{T}_{2}$ - Recommended dose of fertilizer 100:60:60 kg/ha NPK, $\mathrm{T}_{3}-12.5$ tonnes vermicompost/ha, $\mathrm{T}_{4}-10$ tonnes vermicompost /ha, $\mathrm{T}_{5}-7.5$ tonnes vermicompost/ha, $\mathrm{T}_{6}-5$ tonnes vermicompost/ha, $\mathrm{T}_{7}-2.5$ tonnes vermicompost/ha, $\mathrm{T}_{8}-10$ tonnes vermicompost/ha $+25 \% \mathrm{RDF}, \mathrm{T}_{9}-7.5$ tonnes of vermicompost/ha $+50 \% \mathrm{RDF}, \mathrm{T}_{10}-5$ tonnes vermicompost/ha $+75 \% \mathrm{RDF}, \mathrm{T}_{11}-$ 2.5 tonnes of vermicompost/ha $+100 \%$ of RDF. The seeds of bottle gourd were sown in well prepared plot in $4 \mathrm{~m} \times 3 \mathrm{~m}$ plots at spacing of $2 \mathrm{~m} \times 0.5 \mathrm{~m}$ spacing. After transplanting irrigations were applied according to crop condition. Recommended dose of organics, N, $\mathrm{P}_{2} \mathrm{O}_{5}$ and $\mathrm{K}_{2} \mathrm{O}$ were applied as per the schedule of the experiment in the form of vermicompost, urea (CAN), diammonium phosphate (DAP) and muriate of potash (MOP). The whole dose of vermicompost, $\mathrm{P}$ and $\mathrm{K}$ fertilizers was applied at the time of field preparation.

The nitrogen fertilizer was applied in two equal split doses, first dose at the time of seed sowing and second one month after plant emergence. During observation, five plants were selected at random from each plot to record the yield attributes viz., Days taken to appearance of first female flower, Length of main vine.

Fruits yield (q/ha) at marketable maturity was recorded during harvesting. For soil analysis, three representative soil samples from 0-15 $\mathrm{cm}$ depth were collected before seed sowing and after crop harvest for analysis of physicchemical properties following standard procedures (Table 1). Statistical analysis was performed using the SPSS statistical package. 


\section{Results and Discussion}

\section{Yield attributes and yields}

Results of two years data revealed that application of 7.5 tonnes vermicompost and $50 \%$ recommended dose of fertilizers/ha $\left(\mathrm{T}_{9}\right)$ performed the maximum and significant effect (Table 1) on yield attributes followed by $T_{8}$ and $T_{10}$ viz., vine length, number of primary branches per vine, maximum number of fruit per vine and days taken to appearance first female flower reason that source of organic matter from vermicompost supply energy and body building for most of the beneficial micro-organism for their general function, also promoting substances such as vitamin, amino acid, auxin and gibberellins were increased in soil may improved growth of bottle gourd. Similarly, yield of bottle gourd was significantly improved by $97.7-$ $111.0 \%$ in treatments $\mathrm{T}_{8}, \mathrm{~T}_{9}, \mathrm{~T}_{10}, \mathrm{~T}_{11} \& \mathrm{~T}_{3}$ over control due to combined application of organic and inorganic fertilizers due to enhancement in nutrient use efficiencies.

Table.1 Physico-chemical properties of experimental soil in 0-15 $\mathrm{cm}$ depth before the start of experiment

\begin{tabular}{|l|l|}
\hline \multicolumn{1}{|c|}{ Properties } & \multicolumn{1}{c|}{ Methods } \\
\hline Soil reaction (pH) & 1:2.5 soil : water suspension (Jackson, 1973) \\
\hline Soil organic carbon (SOC) & Chromic acid titration (Walkely and Black, 1934) \\
\hline Available nitrogen (N) & Alkaline permanganate (Subbijah and Asija, 1956) \\
\hline Available phosphorus (P) & Ascorbic acid method (Olsen et al., 1954) \\
\hline Available potassium (K) & 1N NH4OAc (pH 7.0) reagent (Merwin and Peech, 1951) \\
\hline
\end{tabular}

Table.1 Influence of organic and inorganic fertilizers on yield attributes and yield of Bottle gourd (Pooled two year data)

\begin{tabular}{|l|c|c|c|c|c|}
\hline Treatments & $\begin{array}{c}\text { Days taken to } \\
\text { appearance of } \\
\text { first female }\end{array}$ & $\begin{array}{c}\text { Length of } \\
\text { main vine } \\
\text { flower }\end{array}$ & $\begin{array}{c}\text { No. of } \\
\text { primary }\end{array}$ & $\begin{array}{c}\text { No. of fruit } \\
\text { per vine }\end{array}$ & $\begin{array}{c}\text { Yield } \\
\text { (q/ha) }\end{array}$ \\
\hline $\mathbf{T}_{\mathbf{1}}$ & 68 & 324 & 9.82 & 8.64 & \\
\hline $\mathbf{T}_{\mathbf{2}}$ & 64 & 433 & 13.52 & 10.92 & 240.04 \\
\hline $\mathbf{T}_{\mathbf{3}}$ & 56 & 418 & 12.42 & 12.04 & 272.52 \\
\hline $\mathbf{T}_{\mathbf{4}}$ & 58 & 416 & 12.30 & 19.82 & 257.12 \\
\hline $\mathbf{T}_{\mathbf{5}}$ & 60 & 409 & 12.14 & 19.65 & 238.28 \\
\hline $\mathbf{T}_{\mathbf{6}}$ & 61 & 390 & 12.02 & 19.21 & 227.63 \\
\hline $\mathbf{T}_{\mathbf{7}}$ & 62 & 381 & 11.92 & 10.92 & 215.44 \\
\hline $\mathbf{T}_{\mathbf{8}}$ & 60 & 389 & 12.62 & 12.08 & 278.75 \\
\hline $\mathbf{T}_{\mathbf{9}}$ & 55 & 440 & 13.56 & 14.24 & 289.60 \\
\hline $\mathbf{T}_{\mathbf{1 0}}$ & 57 & 436 & 13.32 & 13.63 & 282.81 \\
\hline $\mathbf{T}_{\mathbf{1 1}}$ & 58 & 421 & 12.80 & 13.46 & 271.51 \\
\hline $\mathbf{S E m}_{\mathbf{m}}$ & $\mathbf{0 . 5 2}$ & $\mathbf{1 4 . 3 1}$ & $\mathbf{0 . 2 9}$ & $\mathbf{0 . 7 8}$ & $\mathbf{7 . 4 2}$ \\
\hline $\mathbf{L S D}_{(\mathbf{0 . 0 5})}$ & $\mathbf{1 . 4 2}$ & $\mathbf{3 9 . 6 3}$ & $\mathbf{0 . 8 6}$ & $\mathbf{2 . 2 6}$ & $\mathbf{2 1 . 8 1}$ \\
\hline
\end{tabular}


Table.2 Influence of organic and inorganic fertilizers on physic-chemical properties of soil in Bottlegourd (Pooled of two years)

\begin{tabular}{|c|c|c|c|c|c|c|c|}
\hline \multirow[t]{2}{*}{ Treatments } & \multirow[t]{2}{*}{ pH } & \multirow{2}{*}{$\begin{array}{c}\mathrm{EC} \\
\left(\mathrm{dSm}^{-1}\right)\end{array}$} & \multirow{2}{*}{$\begin{array}{l}\text { OC } \\
(\%)\end{array}$} & \multicolumn{4}{|c|}{ Available Nutrient (kg/ha) } \\
\hline & & & & $\mathbf{N}$ & $\mathbf{P}$ & $\mathbf{K}$ & $\mathbf{S}$ \\
\hline $\mathbf{T}_{1}$ & 7.8 & 0.23 & 0.33 & 180.42 & 13.10 & 170.10 & 12.40 \\
\hline $\mathbf{T}_{2}$ & 7.8 & 0.21 & 0.37 & 204.52 & 15.80 & 185.42 & 13.20 \\
\hline $\mathbf{T}_{3}$ & 7.6 & 0.29 & 0.44 & 210.62 & 16.60 & 196.31 & 14.80 \\
\hline $\mathbf{T}_{4}$ & 7.6 & 0.28 & 0.42 & 207.70 & 18.21 & 188.61 & 14.70 \\
\hline $\mathbf{T}_{5}$ & 7.7 & 0.28 & 0.42 & 206.12 & 18.84 & 184.32 & 14.50 \\
\hline $\mathbf{T}_{6}$ & 7.7 & 0.26 & 0.41 & 204.23 & 17.40 & 183.18 & 14.62 \\
\hline $\mathbf{T}_{7}$ & 7.7 & 0.24 & 0.38 & 200.67 & 16.20 & 182.61 & 13.90 \\
\hline $\mathbf{T}_{8}$ & 7.5 & 0.28 & 0.44 & 212.53 & 18.68 & 192.79 & 15.20 \\
\hline $\mathbf{T}_{9}$ & 7.5 & 0.26 & 0.45 & 216.67 & 18.56 & 194.56 & 15.60 \\
\hline $\mathbf{T}_{10}$ & 7.6 & 0.26 & 0.41 & 206.91 & 18.01 & 191.23 & 14.30 \\
\hline $\mathbf{T}_{11}$ & 7.7 & 0.24 & 0.40 & 204.48 & 16.40 & 183.43 & 14.25 \\
\hline SEm \pm & 0.09 & 0.01 & 0.04 & 1.67 & 1.21 & 2.14 & 0.37 \\
\hline $\operatorname{LSD}_{(0.05)}$ & NS & 0.03 & 1.16 & 4.86 & 3.47 & 6.12 & 1.01 \\
\hline
\end{tabular}

\section{Soil physico-chemical properties}

Combinations of organic and inorganic fertilizers proved to beneficial effect after two years on soil physico-chemical properties viz., $\mathrm{pH}, \mathrm{EC}$, organic carbon (OC); and available $\mathrm{N}, \mathrm{P}, \mathrm{K}$ and $\mathrm{S}$. Soil $\mathrm{pH}$ was slightly decreased after crop harvest in treatments $\mathrm{T}_{8} \& \mathrm{~T}_{9}$ due to release of carbonic acid from vermicompost. Soil electrical conductivity was significantly the low in treatment $\mathrm{T}_{2}$ followed by $\mathrm{T}_{7}, \mathrm{~T}_{9}$, $\mathrm{T}_{10} \& \mathrm{~T}_{11}$. In contrast of $\mathrm{pH}$ the soil organic carbon was significantly improved under treatment combination of vermicompost and inorganic fertilizers and recorded the highest $\mathrm{OC}$ in $\mathrm{T}_{9}$ and statistically at par with $\mathrm{T}_{3}$ due to addition of carbonic acid (Bellakki and Badunur, 1997). Similarly, Availability of plant nutrients i.e., available $\mathrm{N}, \mathrm{P}, \mathrm{K} \& \mathrm{~S}$ were also significantly improved in treatments having combination of organic and inorganic fertilizers. The availability of plant nutrients i.e., $\mathrm{N} \& \mathrm{~S}$ were improved by $19.7 \& 25.8 \%$ respectively in treatment $\mathrm{T}_{9}$ over control. Available phosphorus was recorded the highest in treatment $\mathrm{T}_{8}$ which was statistically at par with treatment $\mathrm{T}_{8}, \mathrm{~T}_{10}, \mathrm{~T}_{11} \& \mathrm{~T}_{3}$, and also it was improved by $23.6-42.5 \%$ over control. Available potassium was recorded significantly the highest in treatment having application of only organic fertilizer $\left(\mathrm{T}_{3}-12.5\right.$ tonnes vermicompost/ha) followed by treatment $\mathrm{T}_{8}, \mathrm{~T}_{9} \& \mathrm{~T}_{10}$. Build up of available nutrients after crop harvest due to combined application of vermicompost and inorganic fertilizer which release native unavailable nutrients through diversified microorganism present in vermicompost (Swarup, 1991, Alenkar et al., 2015).

In conclusion on the basis of two years of data application of organic and inorganic fertilizers gave the better yield attributes \& yield as well as availability of plant nutrients in Eastern region of Uttar Pradesh.

\section{References}

Alenkar, A.N., G.N. Hirve P. S. Deshmukhand Kharde, R. P. 2015. 
Study the effect of Integrated Nutrient Management on yield and nutrient uptake in Pumpkin. Journal of Horticulture. 2(2), 1-3.

Bellakki M A and Badanur V P (1997). Long term effect of integrated nutrient management on properties of vertisols under dry land agriculture. Journal of Indian Society of Soil Science 45,43842.

Brady N C and Weil R R(2002). The Nature and Properties of Soils. Thirteen Eddition, pp 498-499.

Jackson, M. L. 1973. Soil Chemical Analysis, Prentise Hall of India Pvt. Ltd, New Delhi.

Merwin HD, Peech M. Exchangeability of soils potassium in the silt and clay fractions as influenced by the nature of the complimentary exchangeable cations. Soil Science Society of American Proceedings. 1951; 15:125128.

Olsen, S. R., C. V. Watanable, F. S.
Watanable and Dean, L. A. 1954. Estimation of available phosphorus in soil by extraction with sodium biocarbonate, USDA, Cercular 939.

Subbiah, B. V. and Asija, G. L. 1956. A rapid procedure for the determination of available nitrogen. Soil. Curr.Sci. 25, 259-260.

Swarup Anand. 1991. Long term effect of green manuring (Susbaniaaculeata) on soil properties and sustainability of rice and wheat yield on a sodic soil. J.IndianSoc.Soil Sci. 39, 777-780.

Thamburaj, S and Singh, N. 2008. Textbook of Vegetables, Tuber crops and Spices Published by Directorate of Information and Publication of Agriculture ICAR,New Delhi pp 271.

Walkley, A. and Block, C. A. 1934. Estimation of organic carbon by chronic acid a rapid titration method. Soil Sci. 37,29-38.

\section{How to cite this article:}

Sanjay Kumar, Satendra Kumar Singh and Surendra Prasad 2020. Organic and Inorganic Sources of Fertilizers Affect the Yield Attributes, Yield of Bottle Gourd [Lagenaria siceraria (Mol.) Standl] and Modified Soil Physico-chemical Properties in Eastern Uttar Pradesh. Int.J.Curr.Microbiol.App.Sci. 9(07): 2191-2195. doi: https://doi.org/10.20546/ijcmas.2020.907.255 